\title{
BANKING BUSINESS MODELS IN UKRAINIAN BANKING SYSTEM
}

\author{
Yuliya ONYSHCHENKO', \\ Odessa National Economic University, Ukraine
}

\begin{abstract}
The purpose of the paper is to work out and characterize bank business models that are formed in Ukraine. Methodology. Our research we will spend among banks that are functioning on the Ukrainian financial market and are not on the stage of liquidation, so the sample under study in our work is comprised of 131 banks which are different in their ownership structure and size. The core of the methodology is a statistical clustering algorithm that allows identifying the groups of banks (clusters) with similar business models as banks with similar business model strategies have made similar choices regarding the composition of their assets and liabilities. The cluster analyses were taken on the base of seven chosen indicators: bank loans, bank liabilities, enterprise loans, enterprise liabilities, household loans, household liabilities and trading assets. Results. The traditional business model of bank is worked out. The bank business models that are functioning in Ukraine are identified on the base of cluster analyses using balance sheet characteristics of 131 Ukrainian banks. We find that in Ukraine were formed three types of bank business models: "Focused retail", "Diversified retail" and "Corporative retail". The description of each model is given. Practical implications. More detailed research of distinguished models allows not only to find out the main advantages and disadvantages of each bank model, but also the main problems that follow the development of Ukrainian banking sector. Identifying of bank models and their studying simplifies searching and elaboration of regulatory instruments as there is a two-way causation between regulation and bank business models. This implies a symbiotic relationship between regulation and bank business models: business models respond to regulation which in turn responds to the evolution of new business models. Value/originality. Such survey is conducted at the first time among Ukrainian banks. The main differences which are between European and Ukrainian bank business models are marked out. Recommendations concerning improving of bank business models in Ukraine are given.
\end{abstract}

Key words: bank, bank business models, traditional bank business model, banking activity, Central Bank, financial regulation.

JEL Classification: G20, G21, L21, L25

\section{Introduction}

Today, Ukrainian banking system is on the new stage of its development that is connected with overcoming of negative influence of the world financial crises and reforming of banking sector with the aim of providing stable and effective banking activity in Ukraine. This process is complicated with instable internal political and economic environment. But successful banking sector reforming depends on the accounting of all its features such as the structural evolution of the financial system and financial markets; the macroeconomic environment in which banks and their customers operate; the decisive impact of EU and national regulation; the competitive environment in banking markets; the existing banking business models. The defining of banking business models contributes to a better understanding of financial and economic performance, risk behavior, and governance at a system level. It also serves to monitor banks' behaviors and their contribution to systemic risk, which can be useful for its regulation.

\footnotetext{
Corresponding author:

${ }^{1}$ Department of Banking, Odessa National Economic University.

E-mail: yulia_pere@rambler.ru
}

The current paper aims to identify business models of Ukrainian banks.

The article is organized in five sections. In the second section, we characterize the traditional banking business model. In the third section, we work out the system of indicators which lets us to classify banks. In the fourth section, we form clusters of banks and characterize them defying business models and highlighting systematic differences in the performance of banks in different groups. In the last section, we look into differences between bank business models that are formed in Europe and Ukraine.

\section{Traditional banking model}

Banks according to their market strategy and balance sheet structure choose to be different from one another. In a competitive pursuit of growth opportunities, banks choose a business model to leverage the strengths of their organization. So bank business models are not static and evolve over time and under the influence of financial market development. 
Before finding out the main banking models that are formed in Ukrainian banking system it is natural to begin with a review of the traditional model of the banking firm that was the dominant model for decades and formed the basis of standard text-book analyses of the banking firm (see Llewellyn, 1999). In this traditional model, financial intermediation is the dominant business of banks which lies in accepting deposits and utilizing their comparative advantages to transform deposits into loans.

A bank is "an institution whose current operations consist in granting loans and receiving deposits from the public" ( X. Freixas and J. C. Rochet, 1997) This definition underlines that the bank main activity is acceptance of deposits and offering of loans, which distinguishes them from other financial intermediaries. However, banks typically conduct a broader range of activities, which can be subsumed under the following three functions (X. Freixas and J. C. Rochet, 1997):

- banks provide the public with liquidity (money) and payment services through their deposit-taking business;

- banks transform assets in terms of denomination, quality and maturity, as well as manage the associated risks;

- banks process information and monitor borrowers using specialized technologies. This activity lets them often establish long-term relationships with their clients, which may further mitigate the negative impacts of adverse selection and moral hazard on the resource allocation process.

So, in the basis of bank activity organization lays a traditional business model that can change in time under the pressure of different factors. On our opinion, to understand the traditional business model of a bank is easier with help of using the Business Model Canvas (Alexander Osterwalder, 2004). The traditional bank business model is represented in table 1.

So, as we can see from the table 1 , the banks are an intermediary between the depositor and the borrower. The traditional business model of a bank is very simple: offer lower interest rate to the depositor and higher interest rate to the borrower. It is important to underline that all depositors and borrowers can be segmented into retail customers, corporate enterprises (small companies, mid-size enterprises and large corporations) and financial intermediaries (often another banks). Also bank can invest its funds into the different types of securities, so the issuers of securities can be referred to the customer segment.

Banks offer different value propositions such as passive banking operations (sourcing of funds, property and legal affairs and maturity), active banking operations (short-and long-term active jobs), neutral banking business (banking transactions and intermediary commission of banking transactions) and its own banking operations (shortterm and long-term banking business) that reach different customer segments in the form of deposit and loan products, investments into the profitable projects, and, of course, trust management. Banks use multiple channels to reach out to their customers such as opening bank branches and establishing ATMs at convenient locations, providing call center, Internet and Mobile banking.

Today, with development of IT technologies and in order to reduce their channel costs and operational risk banks are interested in automation. Electronic banking (e-banking) is a contemporary form of banking that involves the use of modern information and telecommunication technologies in carrying out banking transactions from home, the office, or from business trip, 24 hours a day, 365 days in a year (Cirovic M., 2001).

Banks developed new business models and moved away from the traditional model. Several trends in bank business models emerged in the recent years (David T. Llewellyn, Richard Reid, 2012):

- banks increasingly diversified into more lines of business activity some of which had previously been inhibited with regulation;

- bank assets expanded at a substantially faster rate than that of retail deposits creating an ever-widening 'funding gap';

- the rise in bank loans substantially exceeded the rise in banks' risk-weighted assets held on the balance sheet;

Table 1

\section{The traditional business model of the bank (using Business Model Convas)}

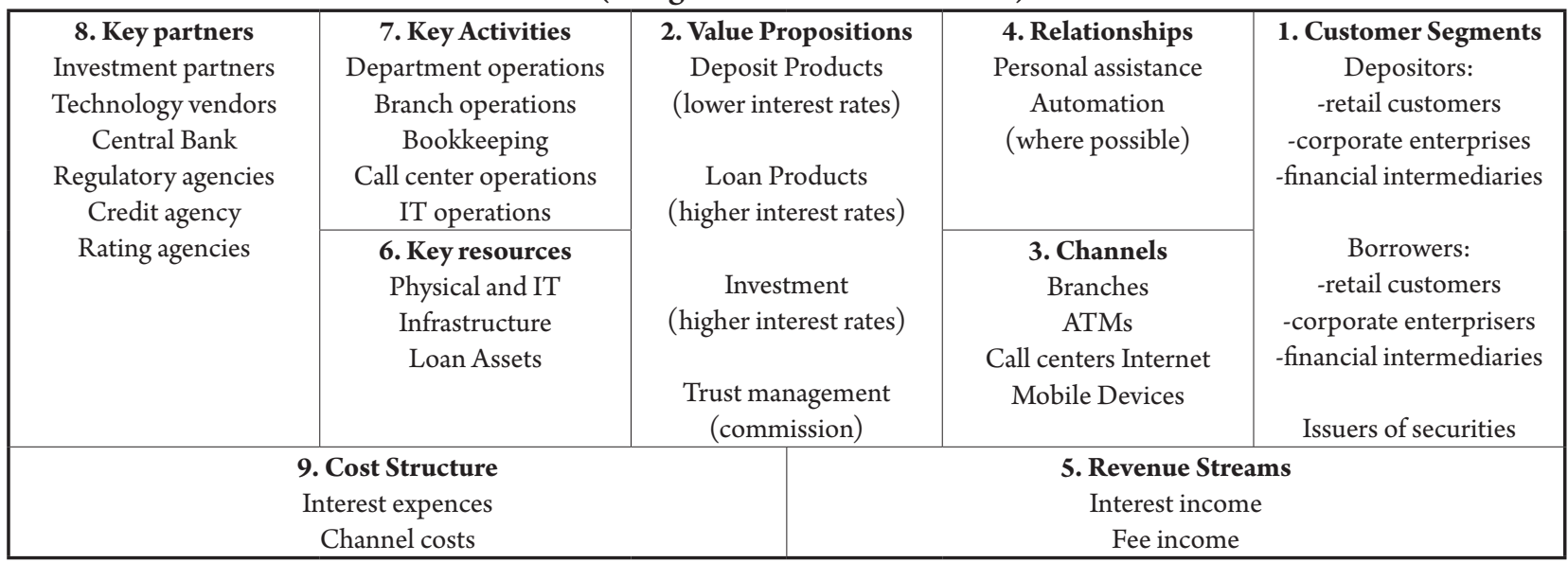


- securitisation of loans became a central business strategy for many banks;

- investment and trading activity increased sharply, and the proportion of traded assets in the total balance sheet rose substantially in many cases;

- banks reduced their holdings of liquid assets as they developed greater access to wholesale funding markets;

- the extent of maturity transformation also increased sharply as increasing use was made of short-maturity money market funding sources;

- an increased dependency on wholesale and money market funding;

- a powerful trend emerged towards using credit derivatives as a means of supposedly shifting credit risk.

So the development of financial system leads to the appearing of different banking models from the traditional one that mainly depends on the banking activity direction in customer service on the financial market.

\section{Classifying banks: the database and the methodology}

Our research we will spend among banks that are function on the Ukrainian financial market. On the first of January, 2015 there was registered 163 banks in the banking system of Ukraine. But we have to underline that 32 banks are on the stage of liquidation what is connected as with economic and political crises in Ukraine, so with Central Bank policy. So the sample under study in our work is comprised of 131 banks which are different in their ownership structure and size.

The core of the methodology is a statistical clustering algorithm. To our mind, the use of cluster analysis allows to identify the groups of banks (clusters) with similar business models. The idea is that banks with similar business model strategies have made similar choices regarding the composition of their assets and liabilities.

Cluster analysis is the task of grouping a set of objects in such a way that objects in the same group (called a cluster) are more similar (in some sense or another) to each other than to those in other groups (clusters). Cluster analysis itself is not one specific algorithm, but the general task to be solved. It can be achieved with various algorithms that differ significantly in their notion of what constitutes a cluster and how to efficiently find them. Popular notions of clusters include groups with small distances among the cluster members, dense areas of the data space, intervals or particular statistical distributions.

Among the methods of cluster analysis the most distribution got the method of k-means clustering. In centroid-based clustering, clusters are represented with a central vector, which may not necessarily be a member of the data set. When the number of clusters is fixed to $\mathrm{k}$, k-means clustering gives a formal definition as an optimization problem: find the k-cluster centers and assign the objects to the nearest cluster center, such that the squared distances from the cluster are minimized. Most k-means-type algorithms require the number of clusters - $\mathrm{k}$ - to be specified in advance, which is considered to be one of the biggest drawbacks of these algorithms.

We make no a priori decisions as to which choice variables are more important in defining business models or as to the general profile of these models. Assuming that a business model is an "abstract representation of an organization, be it conceptual, textual, and/or graphical, of all core interrelated architectural, co-operational, and financial arrangements designed and developed with an organization presently and in the future, as well as all core products and/or services the organization offers, or will offer, based on these arrangements that are needed to achieve its strategic goals and objectives" (Al-Debei, M. M., El-Haddadeh, R., \& Avison, D., 2008) and accounting the traditional bank business model that was worked out earlier, we decided that bank business model depends, first of all, on the customer segments. Only with defining customer segment bank starts to work out its further business model.

To account for these factors collectively seven instruments were used to form the clusters. These were:

- Bank loans (as \% of assets). The indicator measures the scale of wholesale and interbank activities, which proxy for exposures to risks arising from interconnectedness in the banking sector.

- Bank liabilities (as \% of assets). This indicator identifies the share of liabilities of other banks, including deposits, issued debt, and funds obtained from central banks. Banks with greater interbank funding requirements, often due to an excessive reliance on short-term funding, faced severe problems in the earlier phases of the crisis.

- Enterprise loans (as \% of assets). This indicator identifies the share of loans to enterprise and shows what part of credit resources directed to supporting and providing of economic branches development.

Enterprise liabilities (as \% of assets). This indicator identifies the share of deposits from enterprises, in the total balance sheet, indicating a reliance on more traditional funding sources and preference of corporate segment.

Household loans (as \% of assets). This indicator identifies the share of loans to households and shows what part of credit resources directed to retail market.

- Household liabilities (as \% of assets). This indicator identifies the share of deposits from households in the total balance sheet, indicating a reliance on more traditional funding sources.

- Trading assets (as \% of assets). These are defined as non-cash assets other than loans; a greater value would indicate the prevalence of investment activities that are prone to market and liquidity risks.

The procedure of objects clustering on the base of $\mathrm{k}$-means method is realized in a calculable application package "STATISTICA" in the module "Cluster analysis". Cluster analysis was carried out on the base of activity indicators of 131 Ukrainian banks on January, 1, 2015.

It is important to highlight that cluster analysis is an inexact science. The assignment of individual banks to a 
Table 2

Descriptive statistics for each cluster

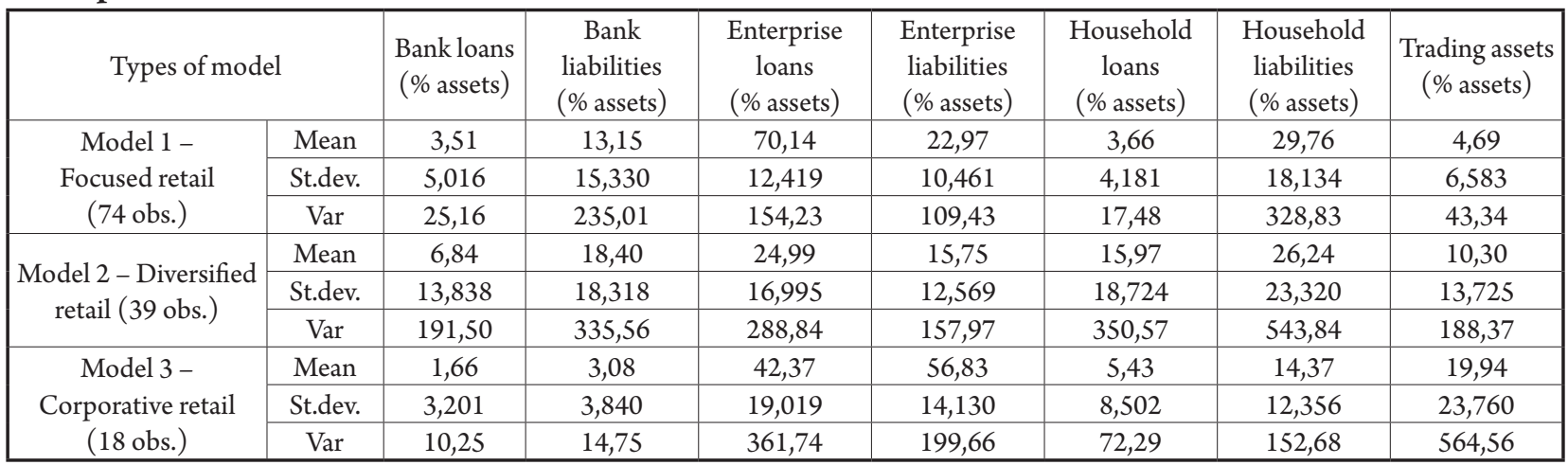

specific cluster, or model, depends crucially on the choice of instruments and procedures, such as the proximity metric, procedures for forming clusters and the stopping rules used.

\section{Bank business models in Ukraine: results of clustering}

The clustering analysis identified four models as the most distinct form of clustering. Table 2 gives the descriptive statistics for the four models resulting from the cluster analysis based on the seven selected balance sheet indicators. Next, an overview of the main structural attributes of the clusters is provided. It is important to highlight once again that the instruments used in the clustering are a subset of the entire set of variables in the sample. Comparison of clusters is given on figure 1.

The first business model group was named "Focused retail", and it is characterized with a high share of enterprise loans on the balance sheet and high reliance on stable funding sources including deposits. In fact, customer (enterprise and household) deposits are about two thirds of the overall liabilities of the average bank in this group. This is the largest group in our research with 74 banks. So this group of banks, in practice, realizes the main task of banking system: transformation of household savings in credit resources for the enterprises that can provide economy growth in future.

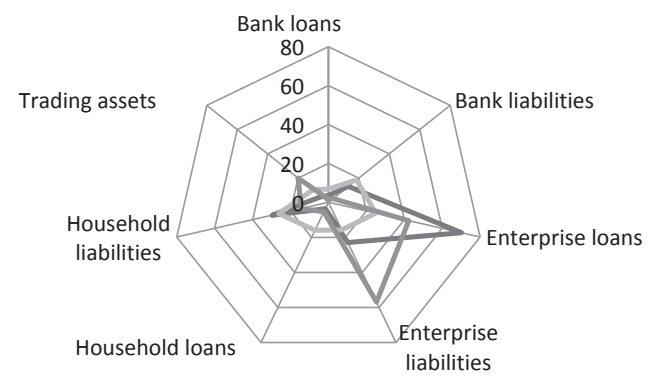

Focused retail $\quad$ Diversified retail $\quad$ Corporative retail

Fig. 1. Comparison of clusters

(values of ratios to total assets in per cent)

Sources: authors' calculation
The second business model group was labeled as "Diversified retail". The banks in this group can be described as universal banks, so they don't have prefers in the one direction of banking activity. They function on the financial market using all channels of attraction and placing resources. This group counts 39 banks.

The third business model group we labeled "Corporative retail” as primarily banks of this group serve enterprises attracting financial resources, giving loans and even making investments. This group counts only 18 banks.

Table 3 characterizes the three business model profiles depending on all seven chosen variables. There is specified the average ratio of all variables for all banks that were classified in the corresponding business model (columns).

Table 3

Business models profiles

(average value of ratios to total assets, \%)

\begin{tabular}{|l|c|c|c|}
\hline \multicolumn{1}{|c|}{ Chosen variebles } & $\begin{array}{c}\text { Focused } \\
\text { retail }\end{array}$ & $\begin{array}{c}\text { Diversified } \\
\text { retail }\end{array}$ & $\begin{array}{c}\text { Corporative } \\
\text { retail }\end{array}$ \\
\hline Bank loans & 3,21 & 7,39 & 2,62 \\
\hline Bank liabilities & 14,21 & 13,75 & 8,63 \\
\hline Enterprise loans & 62,22 & 33,46 & 55,75 \\
\hline Enterprise liabilities & 25,11 & 20,63 & 38,75 \\
\hline Household loans & 4,79 & 14,51 & 4,29 \\
\hline Household liabilities & 28,68 & 25,31 & 20,89 \\
\hline Trading assets & 7,15 & 9,60 & 11,42 \\
\hline
\end{tabular}

Sources: authors' calculation

As we can see from the table, the "Focused retail" model includes banks with the next average structure of their balance sheet: enterprise loans are on the level of $62.22 \%$ and prevail in structure of assets; enterprise and household liabilities are practically on the same level of $25.11 \%$ and $28.68 \%$ respectively. The "Diversified retail" group is characterized with almost uniform structure, so bank liabilities are on the level of $13.75 \%$, enterprise loans $-33.46 \%$, enterprise liabilities $-20.63 \%$, household loans $-14.51 \%$, household liabilities $-28.68 \%$. The third business model "Corporative retail" comprises banks whose main clients are enterprises that are confirmed with the value of variables which characterize the average bank 
of the group. So, enterprise loans and liabilities constitute $55.75 \%$ and $38.75 \%$ accordingly. We don't give out bank loans and trading assets as they are on the lower point in the structure of balance sheet of all banks despite the group that is concern with the economic situation and with practically absence of stock market in our country.

\section{Comparison with another researches in this sphere}

During 2014 there were taken two researches among European banks in this sphere. Ayadi and de Groen (2014) classify European banks into four business models, which they named as investment banks, wholesale banks, diversified retail and focused retail. Rungporn Roengpitya, Nikola Tarashev and Kostas Tsatsaronis (2014) identify three business models which they labeled as "retailfunded", "wholesale-funded" and trading.

We must underline that in this researches the investment bank model corresponds to trading model that includes banks that have substantial trading activities and in funding are focused on less stable and less traditional sources, such as debt, liabilities and, more importantly, repurchase agreements.

The two wholesale models correspond to each other and characterize banks of this group as banks with a heavy reliance on interbank funding and lending which are also very active in non-traditional uses of these funds, including trading assets (i.e. all assets excluding cash, loans and intangible assets.

And at least, the diversified and focused retail models in the first research together correspond to retail-funded model in the second one. So retail-oriented banks used relatively non-traditional funding sources and continued to expand during the crisis, implying that the reliance on multiple sources of financing has reinforced the group's growth prospects. The main difference between the diversified and focused retail models is that while the diversified retail model banks have a greater reliance on debt markets, focused retail model banks rely primarily on customer deposits.

Our research in the Ukrainian banking system shows that on the financial market of Ukraine are absent banks with investment and wholesale business models. Identified business models ("Focused retail", "Diversified retail" and "Corporative retail") of Ukrainian banks relate to the retail-oriented banks. Let's study this problem deeper.

The absence of investment bank is connected with weakly developed stock market in Ukraine. Thus, as to the legislation in Ukraine all banks can be only created in the form of Joint-Stock Company and their shares must be in free float on the stock market. But last one don't become more developed and its capitalization is on the low level in comparison with world stock markets (look figure 2)

Figure 2 shows the world according to free-float equity market capitalization and we can't even see Ukraine on it, that confirm that market capitalization of our country is very low on the level of nearly $4 \$ \mathrm{bn}$.

Ukrainian banks can't also make their investments on the world financial markets according to the foreign exchange control that is provided by Central Bank of Ukraine. If someone wants to make their investments abroad, he must receive the individual license for the certain term depends on the goal of investment.

Connected to the wholesale banks, they can be defined as those one who provide services to other banks or large corporations. The absence of this type banks in Ukraine can be explained with two main reasons.

Firstly, the banks in the Ukrainian banking system are two small in relation to the world banks. The assets of all Ukrainian banks are lower than the assets of the largest world banks (look table 4).

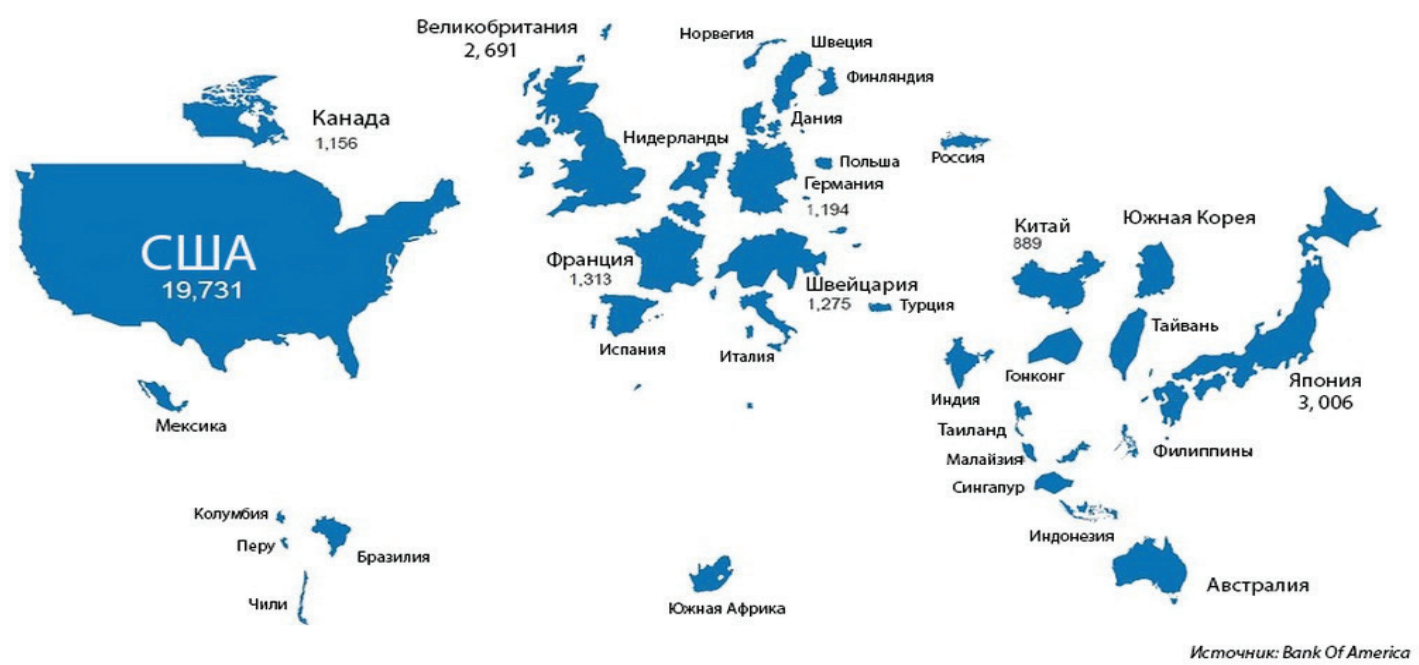

Fig. 2. The world according to free-float equity market capitalization (\$bn)

Sources: Bank of America, 2015 
Table 4

The main indicators of the largest world banks on January, 2015, \$bn

\begin{tabular}{|l|c|c|c|}
\hline \multicolumn{1}{|c|}{ Bank name } & Country & Assets & Capital \\
\hline $\begin{array}{l}\text { Industrial\&Commercial Bank } \\
\text { of China Limited }\end{array}$ & China & 3320,9 & 62,5 \\
\hline $\begin{array}{l}\text { China Construction Bank } \\
\text { Corporation }\end{array}$ & China & 2697,9 & 40,3 \\
\hline $\begin{array}{l}\text { Agricultural Bank of China } \\
\text { Limited }\end{array}$ & China & 2573,9 & 58,8 \\
\hline BNP Paribas SA & France & 2513,6 & 32,6 \\
\hline Bank of China Limited & China & 2457,4 & 58,1 \\
\hline Banking system & Ukraine & 1316,9 & 148,0 \\
\hline
\end{tabular}

Sources: Bank ranking (2015), Key performance indicators of banks in Ukraine

As we can see, assets of Ukrainian banking system are on the level of $1316.9 \$ \mathrm{bn}$. whereas assets of the biggest world bank - Industrial \& Commercial Bank of China Limited are $3320.9 \$ \mathrm{bn}$. that is in 3 times more.

Secondly, the high cost of financial resources on the Ukrainian financial market doesn't make interbank funding and lending attractive to the banks as constant type of banking activity, but this channel can be used as tool to maintain liquidity.

The decision of these two problems in Ukraine leads to the development of banking system that has to play the main role in economic growth of the country. To achieve this goal it is necessary to combine efforts of banking system, under the control of the National bank, government, parliament and President, that must be sent to realization of general task

\section{Conclusions}

The traditional business model of bank on the base of Business Model Convas was worked out. Banks developed new business models and moved away from the traditional model. The trends in bank business model development had been found.

The bank business models that were formed in Ukraine had been identified on the base of cluster analyses using balance sheet characteristics of 131 Ukrainian banks. The cluster analyses were taken on the base of seven chosen indicators: bank loans, bank liabilities, enterprise loans, enterprise liabilities, household loans, household liabilities and trading assets. We found that in Ukraine there were formed three types of bank business models: "Focused retail", "Diversified retail" and "Corporative retail". The description of each model was given according to the variance value in each cluster. It was established that bank business models that functioned in Ukraine differed from those that characterize European banks. The main reasons of absence such bank business models as investment and wholesale were analyzed.

\section{References}

Al-Debei, M. M., El-Haddadeh, R., \& Avison, D. (2008). "Defining the business model in the new world of digital business." In Proceedings of the Americas Conference on Information Systems (AMCIS), Vol. 2008, pp. 1-11.

Alexander Osterwalder (2004). The Business Model Ontology - A Proposition In A Design Science Approach. PhD thesis University of Lausanne. [Electronic resource]. - Retrieved from: http://www.hec.unil.ch/aosterwa/ $\mathrm{PhD} /$ Osterwalder_PhD_BM_Ontology.pdf

Ayadi, R and W de Groen (2014): Banking business models monitor 2014 - Europe, Centre for European Policy Studies and International Observatory on Financial Services Cooperatives. [Electronic resource]. - Retrieved from: https://www.ceps.eu/system/files/Banking\%20Business\%20Models \%202014.pdf

Bank of America, Merrill Lynch (2015). LBofAML's Transforming World Atlas, 04 August 2015 [Electronic resource]. - Retrieved from: http://www.bofaml.com/content/dam/boamlimages/documents/PDFs/ bofamlatwatlas.pdf

Bank ranking (2015) - Top banks in the world. [Electronic resource]. - Retrieved from: http://www.accuity.com/ useful-links/bank-rankings/

David, T. Llewellyn (1999). Institutional structure of financial regulation and supervision: the basic issues. Paper presented at a World Bank seminar Aligning Supervisory Structures with Country Needs Washington DC. [Electronic resource]. - Retrieved from: http://siteresources.worldbank.org/INTTOPCONF6/ Resources/2057292-1162909660809/F2Flemming Llewellyn.pdf

Cirovic, M. (2001). Bankarstvo, Bridge Company, Beograd, 2001.

David T. Llewellyn, Richard Reid (2012). Future risks and fragilities for financial stability, Vienna: SUERF. [Electronic resource]. - Retrieved from: https://www.suerf.org/docx/s 57f04bb2975420e3b4c73920c687 cad7_3399_suerf.pdf

Key performance indicators of banks in Ukraine. [Electronic resource]. - Retrieved from: http://www.bank.gov.ua/ control/en/publish/article?art id=37942\&cat id=37937

Rungporn, Roengpitya, Nikola Tarashev, Kostas Tsatsaronis (2014). Bank business models BIS Quarterly Review, December 2014. [Electronic resource]. - Retrieved from: http://www.bis.org/publ/qtrpdf/r_qt1412g.htm

Freixas, X. and Rochet, J. C. (1997). The Microeconomics of Banking, MIT Press. [Electronic resource]. - Retrieved from: https://mitpress.mit.edu/sites/default/files/titles/content/9780262062701_sch_0001.pdf 


\section{ЮЛИЯ ОНИЩЕНКО \\ БИЗНЕС МОДЕЛИ БАНКОВ В БАНКОВСКОЙ СИСТЕМЕ УКРАИНЫ}

Аннотация. Целью работы является выделение и характеристика бизнес моделей банков, которые сформировались в Украине. Методика. Наше исследование мы проводили среди банков, которые функционируют на украинском финансовом рынке и не находятся в стадии ликвидации. Таким образом, выборка в нашей работе охватывает 131 банк, которые отличаются по структуре собственников и размеру. Основой исследования стал статистический кластерный алгоритм, который позволил определить группы банков (кластеры) с похожими бизнес моделями. Отметим, что банки с похожими бизнес моделями принимают практически одинаковые решения при пересмотре и формировании своих активов и обязательств. Кластерный анализ проводился на базе семи показателей: кредиты банкам, средства банков, кредиты юридическим лицам, средства юридических лиц, кредиты физических лиц, средства физических лиц, инвестиционный портфель. Результаты. Традиционная бизнес модель банка была разработана. Бизнес модели банков, которые функционируют в Украине, были определены на базе кластерного анализа с использованием балансовых показателей 131 банка в Украине. Было выделено три модели банков, которые сформировались в Украине. Описание каждой модели было проведено. Практическое значение. Более подробное исследование выделенных бизнес моделей банков в будущем позволит определить основные преимущества и недостатки каждой модели, а также выявить основные проблемы, которые сопровождают развитие отечественной банковской системы. Определение бизнес моделей банков и их изучение позволит упростить исследование и выбор инструментов регулирования для каждой банковской бизнес модели, так как между ними существует двухстороння связь. Значение/оригинальность. Подобное исследование среди украинских банков проводилось впервые. Основные различия между европейскими и украинскими бизнес моделями банков были выделены. Рекомендации относительно улучшения бизнес моделей банков Украины были разработаны. 